Article

\title{
Bio-Oxidation of a Double Refractory Gold Ore and Investigation of Preg-Robbing of Gold from Thiourea Solution
}

\author{
Rui Xu, Qian Li, Feiyu Meng *, Yongbin Yang, Bin Xu, Huaqun Yin and Tao Jiang \\ School of Minerals Processing and Bioengineering, Central South University, Changsha 410083, China; \\ ruixu1923@csu.edu.cn (R.X.); csuliqian208018@csu.edu.cn (Q.L.); ybyangcsu@126.com (Y.Y.); \\ xubincsu@csu.edu.cn (B.X.); yinhuaqun_cs@sina.com (H.Y.); jiangtao@csu.edu.cn (T.J.) \\ * Correspondence: meiyu1616585@163.com; Tel.: +86-135-4050-3028
}

Received: 13 August 2020; Accepted: 4 September 2020; Published: 10 September 2020

\begin{abstract}
Carbonaceous sulfidic gold ores are commonly double refractory and thus require pretreatment before gold extraction. In this paper, the capacity of pre-bio-oxidation can simultaneously decompose sulfides or deactivate carbonaceous matters (CM) from a double refractory gold ore (DRGO) using pure cultures of A. ferrooxidans or L. ferrooxidans, and a mixed culture containing A. ferrooxidans and L. ferrooxidans was investigated. The results showed that direct thiourea leaching of the as-received DRGO yielded only $28.7 \%$ gold extraction, which was due to the encapsulation of sulfides on gold and the gold adsorption of CM. After bio-oxidation, thiourea leaching of the DRGO resulted in gold extraction of over 75-80\%. Moreover, bio-oxidation can effectively reduce the adsorption of carbon to gold. XRD, SEM-EDS and FTIR analysis showed that many oxygen-containing groups were introduced on the surface of DRGO during bio-oxidation, while the $\mathrm{C}=\mathrm{C}$ bond was cleaved and the $\mathrm{O}-\mathrm{C}-\mathrm{O}$ and $\mathrm{C}-\mathrm{N}$ bonds were degraded, causing a decrease in active sites for gold adsorption. Moreover, passivation materials such as jarosite were formed on the surface of DRGO, which might reduce the affinity of CM for gold in solutions. In addition, the cleavage of the S-S band indicated that sulfides were oxidized by bacteria. This work allows us to explain the applicability of pre-bio-oxidation for degrading both sulfides and CM and increasing gold recovery from DRGO in the thiourea system.
\end{abstract}

Keywords: double refractory gold ore; bio-oxidation; preg-robbing; thiourea leaching; green technology

\section{Introduction}

Environmentally friendly gold extraction from refractory ores has gradually dominated gold production, with a decrease in the quality of gold ores [1]. Currently, refractory gold ores account for around one-third of the total gold production of natural ores, and their refractory behavior is mainly due to the fact that the fine gold particles are often encased in sulfide matrices such as pyrite and arsenopyrite, or the leached gold are preg-robbed by carbonaceous matters (CM) [2-4]. In some cases, the gold ore contains both sulfide minerals and $\mathrm{CM}$, and it can be classified as a double refractory gold ore (DRGO), which is usually abandoned for economic reasons [5]. In such ores, the gold is encased in sulfides, which prevents direct contact between the leaching reagent and gold particles, thus interfering with the dissolution of the gold [6]. Moreover, $\mathrm{CM}$ has a good affinity for dissolved gold complex (preg-robbing), leading to gold losses [7,8]. Commercially, pretreatment of the DRGO is required in order to degrade sulfides and deactivate CM prior to leaching to improve gold extraction [9].

Bio-oxidation has been proven to be a viable pretreatment process for DRGO, which can reduce the consumption of chemical solvents for gold leaching in subsequent operations. It presents 
several attractive features such as environmental friendliness and low cost [10-12]. The commonly used large-scale leaching bacteria now mainly include Acidithiobacillus ferrooxidans (A. ferrooxidans), Leptospirillum ferrooxidans (L. ferrooxidans) and Acidithiobacillus thiooxidans [13]. These autotrophic bacteria are reliant on oxidizing ferrous $\left(\mathrm{Fe}^{2+}\right)$ to ferric $\left(\mathrm{Fe}^{3+}\right)$ ion or oxidizing sulfur compounds or elemental $\mathrm{S}$ to $\mathrm{H}_{2} \mathrm{SO}_{4}$ as their energy source $[2,14]$. This enables bacteria to oxidize and decompose the sulfide matrices, releasing the entrapped gold. In addition, there are two main types of views on the interaction between microorganisms and $\mathrm{CM}$, reflecting the passivation and degradation of $\mathrm{CM}$ by microorganisms and their metabolites. It is reported that Phanerochaete chrysosporium (P. chrysosporium) can secrete manganese peroxidase, lignin peroxidase and oxidative enzymes during metabolism, which are capable of degrading aromatic CM [15-17]. Ofori-Sarpong et al. [18,19] used P. chrysosporium to deactivate different grades of $\mathrm{CM}$ and found that biotransformation of $\mathrm{CM}$ reduced the graphitization of carbon and increased the oxygen content and average pore diameter, which limited the adsorption of gold by CM. Amankwah et al. [20] also pointed out in a two-stage microbial process that Streptomyces setonii has the ability to degrade $\mathrm{CM}$, and gold extraction increased by $13.6 \%$ after degradation of $\mathrm{CM}$. This may be due to the production of alkaline metabolites which was responsible for CM degradation. Though there have been numerous studies on biological pretreatment of DRGO, the results are rather controversial, and there is no general agreement about whether A. ferrooxidans and L. ferrooxidans can simultaneously decompose sulfides and deactivate $\mathrm{CM}$. Moreover, according to previous studies, the mixed bacteria could result in synergistic effects that can improve the bio-oxidation efficiency [21-23]. Up to now, there has not been a clear correlation between the mixture of these two dominant strains and the efficiency of the bio-oxidation process. Thus, it is interesting to compare the behavior of A. ferrooxidans, L. ferrooxidans and a mixed culture composed of $A$. ferrooxidans and $L$. ferrooxidans in a bio-oxidation of DRGO system.

Cyanidation is generally used for leaching gold ores because of its high stability, low cost and simple process [24,25]. However, its poor selectivity, slow leaching kinetics and harmful environmental effects have called for an alternative lixiviant. Thiourea has been considered to be a promising alternative to cyanide due to its high leaching rates and good selectivity [26], and it can be used to leach refractory gold ores containing sulfides (such as pyrite and arsenopyrite) or carbonaceous sulfides [27].

The initial leaching rate of gold at high concentration thiourea is comparable to that of cyanide leaching [28]. Thiourea is a water-soluble organic compound, which is relatively stable in acidic solutions but decomposes rapidly in basic solutions. Therefore, thiourea leaching of gold is normally carried out in a $\mathrm{pH}$ range of 1-2 [29]. In acidic solutions, thiourea dissolves gold and forms a cationic complex; this reaction is rapid and gold extractions can reach 99\% [30]. Previous research has revealed that gold particles only dissolve in thiourea solutions in the presence of oxidizing agents, and ferric sulfate has been shown to be the most effective [31]. The dissolution of gold in thiourea solutions can be expressed as the following reaction.

$$
\mathrm{Au}+2 \mathrm{CS}\left(\mathrm{NH}_{2}\right)_{2}+\mathrm{Fe}^{3+}=\mathrm{Au}\left(\mathrm{CS}\left(\mathrm{NH}_{2}\right)_{2}\right)_{2}^{+}+\mathrm{Fe}^{2+}
$$

Unlike the cyanide system, no adequate explanation for gold adsorption by CM in the thiourea system has been made in previous studies. The available literature indicates that the ability of $\mathrm{CM}$ to adsorb gold in cyanide, thiourea and thiosulfate systems is in the order of $\mathrm{Au}(\mathrm{CN})_{2}{ }^{-}>\mathrm{Au}\left(\mathrm{CS}\left(\mathrm{NH}_{2}\right)_{2}\right)_{2}{ }^{+}$ $>\mathrm{Au}\left(\mathrm{S}_{2} \mathrm{O}_{3}\right)_{2}{ }^{3-}$ [32]. This conclusion has been proven by Ofori-Sarpong and Osseo-Asare [19]. It has also been reported that $\mathrm{CM}$ can adsorb not only gold but also thiourea, and the adsorbed gold is difficult to elute [33]. Considering the potential of thiourea to be used as an alternative to cyanide, it is necessary to evaluate the behavior of preg-robbing of CM in the thiourea system.

The objective of this study was to investigate the ability of decomposing sulfides and decreasing gold adsorption on CM by using pure cultures of $A$. ferrooxidans or L. ferrooxidans and a mixed culture composed of $A$. ferrooxidans and L. ferrooxidans in a thiourea system, so as to assess the potential of A. ferrooxidans and L. ferrooxidans for the pretreatment of DRGO. This work can help to expand the 
current understanding of the biological pretreatment of DRGO by A. ferrooxidans and L. ferrooxidans, especially the impact of the pretreatment on the preg-robbing of CM for gold in the thiourea system.

\section{Experimental}

\subsection{Materials}

The DRGO was obtained from a gold mine in Yunnan Province, China. The ore was finely ground to a particle size of $90.0 \%<0.074 \mathrm{~mm}$. The chemical component analysis showed that the gold content in this ore was $18.05 \mathrm{~g} / \mathrm{t}$, and the ore had high contents of C (6.95\%) and S (20.76\%) (Table 1). The elemental and organic carbon that has a preg-robbing effect on gold accounted for $75.40 \%$ of the total carbon [8]. Mineralogical studies of Au showed that only 1.72\% of gold was exposed and $87.31 \%$ was encapsulated in arsenopyrite and pyrite.

Table 1. Chemical composition and the phase constitution analysis of $\mathrm{C}$ and $\mathrm{Au}$ of the double refractory gold ore.

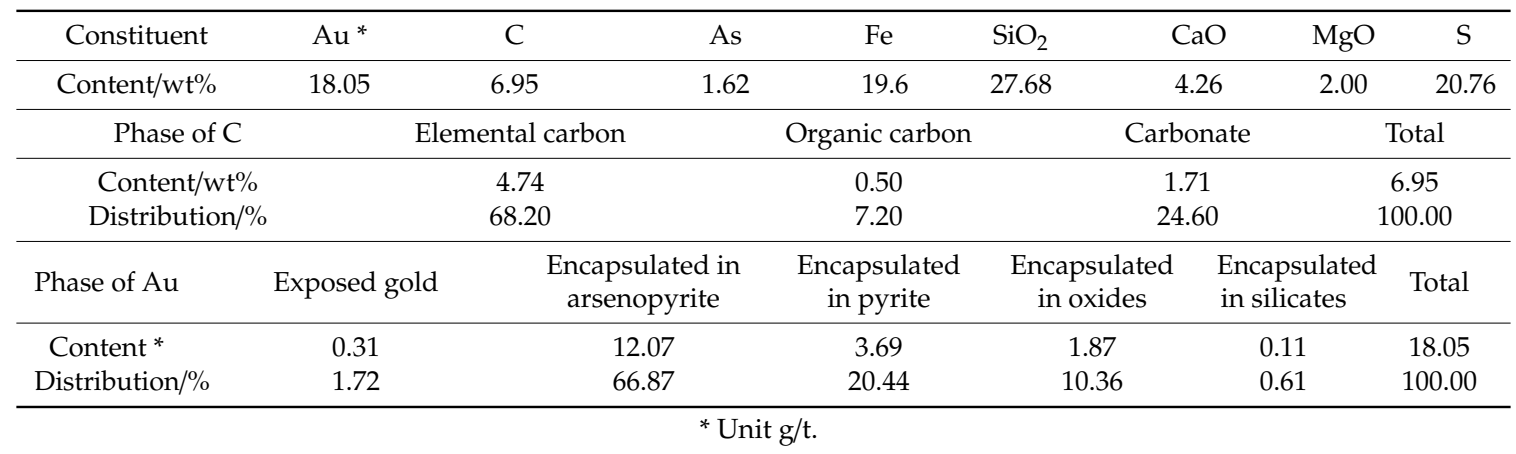

\subsection{Microorganisms}

A. ferrooxidans and L. ferrooxidans were obtained from the Key Lab of Biohydrometallurgy of Ministry of Education, Central South University, Changsha, China. Bacterial cells were cultivated in $100 \mathrm{~mL}$ of $9 \mathrm{~K}$ medium in $250 \mathrm{~mL}$ Erlenmeyer flasks were located in a shaking incubator at $30^{\circ} \mathrm{C}$ and $160 \mathrm{rpm}$. The initial solution $\mathrm{pH}$ was adjusted to 1.8 using $3 \mathrm{M}$ sulfuric acid. The $9 \mathrm{~K}$ medium

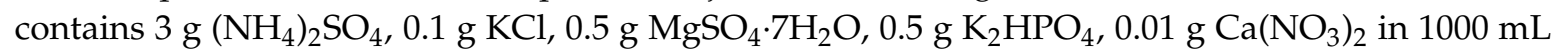
deionized water. In addition, $44.7 \mathrm{~g} / \mathrm{L}$ of $\mathrm{FeSO}_{4} \cdot 7 \mathrm{H}_{2} \mathrm{O}$ was supplemented as the energy source for strains. For domestication, the microorganisms were serially cultured in $9 \mathrm{~K}$ medium in the presence of $10 \mathrm{~g} / \mathrm{L}$ DRGO particles for three months prior to bio-oxidation experiments.

All chemical reagents used in this study were analytically graded, and all solutions were prepared with ultrapure water.

\subsection{Bio-Oxidation Experiments}

The bio-oxidation experiments were conducted in $250 \mathrm{~mL}$ flasks containing $100 \mathrm{~mL} 9 \mathrm{~K}$ medium, and the pulp density was $10 \mathrm{~g} / \mathrm{L}$ of DRGO. Inoculations were separately achieved with $20 \mathrm{~mL}$ inoculum of $A$. ferrooxidans and L. ferrooxidans which had adapted to the DRGO (Section 2.2), and the cell concentration in the two inoculated solutions was around $10^{8}$ cells $/ \mathrm{mL}$. The flasks were located in a shaking incubator at $160 \mathrm{rpm}$ and $30^{\circ}$ for 8 days, with an initial $\mathrm{pH}$ of 1.8 . In this study, A. ferrooxidans and $L$. ferrooxidans were mixed in $1: 1(v / v)$ culture to obtain a mixed culture. The experimental conditions of bio-oxidation using the mixed culture were the same as those using pure cultures. Parallel experiments without bacterial inoculation, but with the same medium and DRGO, were performed as sterile control.

During the bio-oxidation process, $\mathrm{pH}$ and redox potential (Eh) were measured daily, and aliquot samples were periodically taken from the supernatant of each flask for determining total concentrations 
of Fe and As, as well as total organic carbon (TOC). The pulp from the bio-oxidation experiment was filtered with a neutral filter paper at different phases, rinsed with copious ultrapure water and dried in a vacuum dryer at $35^{\circ} \mathrm{C}$ overnight to obtain the residue for the subsequent preg-robbing studies, thiourea leaching process and other analyses.

\subsection{Preg-Robbing Experiments}

The thiourea leaching solution with known gold concentration $(2.612 \mathrm{mg} / \mathrm{L})$ was used for the preg-robbing experiments. Triplicate samples of as-received and bio-oxidized DRGO (each weighing $0.5 \mathrm{~g}$ ) were contacted with $100 \mathrm{~mL}$ of $2.612 \mathrm{mg} / \mathrm{L}$ gold solution and agitated with a magnetic stirrer at a rotating speed of $400 \mathrm{rpm}$ at $30^{\circ} \mathrm{C}$ for $3 \mathrm{~h}$. The initial $\mathrm{pH}$ of the solution was adjusted to around 1.5. After the preg-robbing experiments, the residual solutions were subsequently separated by filtration for the analysis of gold concentration. The difference in gold concentration between as-received and bio-oxidized DRGO gave an indication of the effect of A. ferrooxidans and L. ferrooxidans on preg-robbing for gold by the DRGO.

\subsection{Thiourea Leaching Experiments}

Leaching experiments were carried out in a $200 \mathrm{~mL}$ beaker using an agitator. Each beaker contained $10 \mathrm{~g}$ samples of as-received and bio-oxidized DRGO, respectively, and the liquid-solid ratio was set at 5:1. Then, each beaker was supplemented with $14 \mathrm{~g} / \mathrm{L}$ of ferric sulfate, and the initial $\mathrm{pH}$ was adjusted to 1.5. Finally, thiourea was added to each beaker in a quantity of $6 \mathrm{~g} / \mathrm{L}$. The formed pulp was agitated at $400 \mathrm{rpm}, 30^{\circ} \mathrm{C}$ and the experiments lasted for $4 \mathrm{~h}$. Triplicate leaching experiments were performed under identical conditions. After the experiment, the pulp was filtered and the concentration of gold was measured.

\subsection{Thermodynamic Calculation}

The bio-oxidation process was based on the redox reactions occurring in an aqueous electrochemical system. To illustrate the thermodynamic probability of the formation of intermediate products during the bio-oxidation process of arsenopyrite and pyrite, the Eh-pH diagrams of Fe-As-S- $\mathrm{H}_{2} \mathrm{O}$ and Fe-S- $\mathrm{H}_{2} \mathrm{O}$ systems were implemented using the thermodynamic software HSC Chemistry 6.0. In addition, some special species, such as $\mathrm{H}_{3} \mathrm{OFe}_{3}\left(\mathrm{SO}_{4}\right)_{2}(\mathrm{OH})_{6}, \mathrm{H}_{2} \mathrm{~S}$ and $\mathrm{SO}_{4}{ }^{2-}$, are so thermodynamically stable that they would be preferentially shown in the $\mathrm{E}-\mathrm{pH}$ diagram. Therefore, to reflect the dissolution of arsenopyrite and pyrite and the possible intermediate products in the process of thiourea leaching, the thermodynamic calculation was conducted by considering or neglecting some of the special species. The thermodynamic data were available from the software itself. The temperature and pressure were respectively set at $25^{\circ} \mathrm{C}$ and $1 \mathrm{~atm}$ in the process of plotting the diagrams, within the ranges of Eh $(-1-1 \mathrm{~V})$ and $\mathrm{pH}$ value (0-6). Moreover, the concentration of $\mathrm{Fe}^{2+}$ used to plot the diagrams was $0.16 \mathrm{~mol} / \mathrm{L}$, and the concentration of FeAsS was $7.4 \times 10^{-4} \mathrm{mmol} / \mathrm{L}$ and $\mathrm{FeS}_{2}$ was $3 \times 10^{-4} \mathrm{mmol} / \mathrm{L}$ (i.e., around $10 \mathrm{~g} / \mathrm{L}$ DRGO).

\subsection{Analysis Methods}

The $\mathrm{pH}$ and Eh were measured using a $\mathrm{pH}$ meter (PHSJ-4A, Shanghai Leici, Shanghai, China) equipped with a Pt electrode and a standard $\mathrm{Ag} / \mathrm{AgCl}$ (saturated $\mathrm{KCl}$ ) as a reference electrode. The total concentrations of $\mathrm{Fe}$, As and $\mathrm{Au}$ in the solutions were detected by inductively coupled plasma-atomic emission spectrometer (ICP-AES) (PS-6, Baird, TX, USA). TOC concentration in the sample was analyzed using a total organic carbon analyzer ( $\mathrm{LCPH}$, Shanghai, China). The contents of $\mathrm{C}, \mathrm{Fe}, \mathrm{As}$ and $\mathrm{S}$ in the DRGO were determined by X-ray fluorescence (XRF, Panakot, Netherlands). Mineralogical compositions of as-received and bio-oxidized DRGO were analyzed by X-ray diffractometer (XRD) (D/Max 2500, Rigaku, Tokyo, Japan). The morphology of as-received and bio-oxidized DRGO was examined using a scanning electron microscope (SEM) (Helios NanoLab G3 UC, FEI, Hillsboro, OR, USA) equipped with X-ray energy dispersive analysis (EDS). The chemical bonds and functional groups 
of as-received and bio-oxidized DRGO were analyzed by Fourier transform infrared spectroscopy (FTIR) (IRAffinity-1, Shimadzu, Kyoto, Japan), and the KBr disk method was employed in the wavelength range of 4000 to $400 \mathrm{~cm}^{-1}$ with a resolution of $4 \mathrm{~cm}^{-1}$.

\section{Results and Discussion}

\subsection{Bio-Oxidation Behavior of DRGO}

Variations in the parameters of the solution over time during the bio-oxidation process of DRGO using different bacterial cultures are shown in Figure 1. As can be seen from Figure 1a, the pH increased from 1.8 to 2.26-2.29 within 1 day for all samples except for the sterile control, in which it did not change significantly throughout the entire process. This was due to the fact that $A$. ferrooxidans and L. ferrooxidans were able to oxidize $\mathrm{Fe}^{2+}$ to $\mathrm{Fe}^{3+}$ to obtain energy, with a mass of $\mathrm{H}^{+}$being consumed at this time, and it could be summarized by Equation (3). Furthermore, the $\mathrm{pH}$ increase might be caused by the decomposition of a small amount of alkaline mineral presented in the DRGO [34]. After this period, $\mathrm{pH}$ started to decrease due to the fact that the oxidation and decomposition of sulfide produced acid (Equations (4)-(7)). The Eh generally indicated bacterial activity and bio-oxidation efficiency during the bio-oxidation process (Figure 1b). The Eh within the range of 330-390 $\mathrm{mV}$ was detected in the sterile control, while a remarkable initial increase in Eh values was detected in the bacterial system, reaching 595-627 $\mathrm{mV}$ after 8 days, which was conducive to decomposing the sulfide minerals [35]. This was mainly because the Eh in the bio-oxidation solution was related to the $\mathrm{Fe}^{3+} / \mathrm{Fe}^{2+}$ ratio using the Nernst equation (Equation (2)), and it was documented that the oxidation rate of $\mathrm{Fe}^{2+}$ in the bio-oxidation process was $10^{5}$ to $10^{6}$ times faster than that in the non-bio-oxidation process at low $\mathrm{pH}$ $(<3)$ [36]. Figure 1c clearly shows that the total Fe concentration decreased for all the samples as the bio-oxidation reaction proceeded, except for the sterile control. This was because $\mathrm{Fe}^{3+}$ was extremely unstable in almost all environmental conditions except for high Eh and low $\mathrm{pH}$, and it could rapidly form hydroxides or iron oxides such as jarosite (Equation (8)).

$$
E=E^{\theta}+\frac{R T}{Z F} \ln \frac{\mathrm{Fe}^{3+}}{\mathrm{Fe}^{2+}}
$$
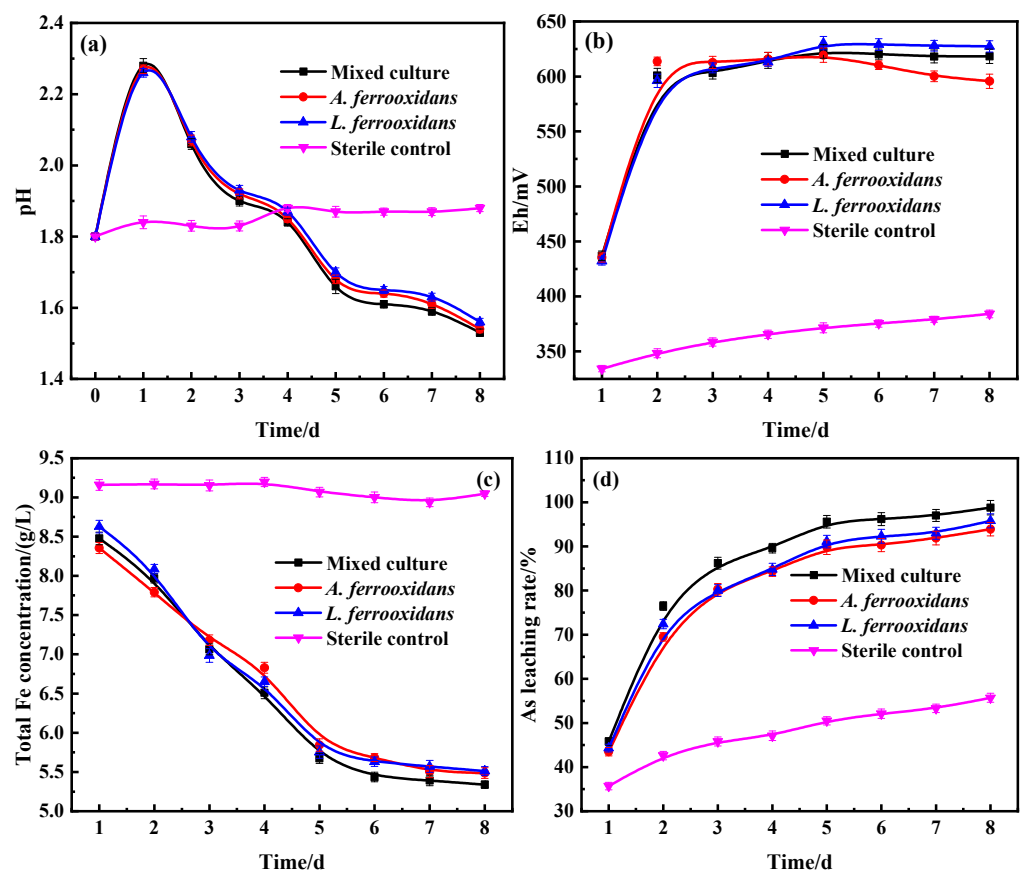

Figure 1. Cont. 


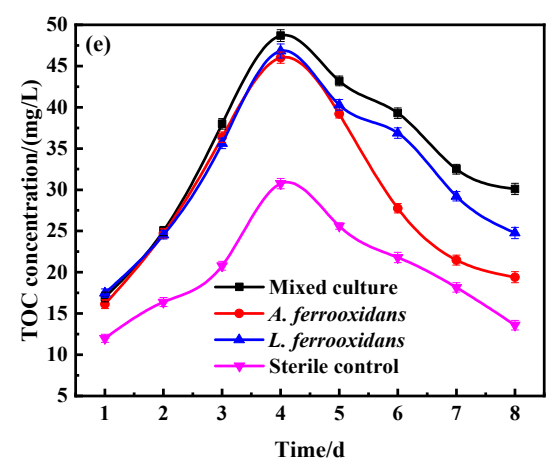

Figure 1. Variations in the (a) $\mathrm{pH}$; (b) Eh; (c) total Fe concentration; (d) As leaching rate; (e) TOC concentration over time during the oxidation process of DRGO.

Figure $1 \mathrm{~d}$ generally shows that both $A$. ferrooxidans and $L$. ferrooxidans were able to decompose arsenopyrite (that encapsulated $66.87 \%$ of gold) in DRGO, and the As removal efficiency of mixed cultures achieved the highest value $(98.8 \%)$. As will be shown in the subsequent thiourea leaching experiments, this result is consistent with the gold recovery rate $(>80 \%)$. In terms of removal efficiency, the effect of the different cultures on As removal could be ranked as follows: mixed cultures $>$ L. ferrooxidans $>$ A. ferrooxidans $>$ sterile control. The oxidation of As could be explained as stated in Equation (5). It is well known that this oxidation occurs through a polysulfide pathway previously described by Shippers and Sand [37] and clearly confirmed by Rohwerder et al. [38]. The changes in TOC concentration in the solutions are shown in Figure 1e, which presented a trend of increasing first and then decreasing during the oxidation process of $\mathrm{CM}$, indicating that some organic carbon fractions in the ore were solubilized when the sulfur and arsenic were oxidized. After 4 days, the TOC values tended to decrease until the end of the experiment, which might be caused by the lack of energy, restraining the bacterial activity, and the TOC started to adhere to the surface of the ore. In addition, the change range of TOC concentration in the sterile system was weaker than the bacterial systems, which was possibly caused by its much slower chemical oxidation.

$$
\begin{gathered}
4 \mathrm{Fe}^{2+}+\mathrm{O}_{2}+4 \mathrm{H}^{+} \stackrel{\text { bacteria }}{\rightarrow} 4 \mathrm{Fe}^{3+}+2 \mathrm{H}_{2} \mathrm{O} \\
2 \mathrm{~S}^{0}+3 \mathrm{O}_{2}+2 \mathrm{H}_{2} \mathrm{O} \stackrel{\text { bacteria }}{\rightarrow} 4 \mathrm{H}^{+}+2 \mathrm{SO}_{4}{ }^{2-} \\
\mathrm{FeAsS}+5 \mathrm{Fe}^{3+}+3 \mathrm{H}_{2} \mathrm{O} \rightarrow 6 \mathrm{Fe}^{2+}+\mathrm{H}_{3} \mathrm{AsO}_{3}+\mathrm{S}^{0}+3 \mathrm{H}^{+} \\
2 \mathrm{Fe}^{3+}+2 \mathrm{H}_{3} \mathrm{AsO}_{4} \rightarrow 2 \mathrm{FeAsO}_{4}+6 \mathrm{H}^{+} \\
\mathrm{FeS}_{2}+14 \mathrm{Fe}^{3+}+8 \mathrm{H}_{2} \mathrm{O} \rightarrow 15 \mathrm{Fe}^{2+}+16 \mathrm{H}^{+}+2 \mathrm{SO}_{4}^{2-} \\
3 \mathrm{Fe}^{3+}+\mathrm{K}^{+}+6 \mathrm{H}_{2} \mathrm{O}+2 \mathrm{SO}_{4}^{2-} \rightarrow \mathrm{KFe}_{3}\left(\mathrm{SO}_{4}\right)_{2}(\mathrm{OH})_{6}+6 \mathrm{H}^{+} \\
\mathrm{FeS}_{2}+2 \mathrm{Fe}^{3+} \rightarrow 3 \mathrm{Fe}^{2+}+2 \mathrm{~S}^{0}
\end{gathered}
$$

\subsection{Characterization of DRGO}

\subsubsection{Mineralogical Composition Analysis by XRD}

The XRD patterns of as-received, bio-oxidized and sterile control DRGO are shown in Figure 2. It can be seen that the DRGO consisted of muscovite, graphite, quartz, arsenopyrite and pyrite, etc. Evidently, photocatalysts with the bio-oxidized DRGO exhibited similar XRD patterns, with peaks at $17.37^{\circ}(012), 28.78^{\circ}(021), 45.55^{\circ}$ (303) and $50.08^{\circ}(220)$, which corresponded to the jarosite or ammoniojarosite phase. This was consistent with the results in Figure 1d, meaning that the oxidative dissolution of Fe-bearing sulfides was caused by A. ferrooxidans and L. ferrooxidans but not observed obviously in the sterile control. This finding was consistent with the work of Nazari et al. [39] in 
which A. ferrooxidans was used to investigate jarosite formation during the bioleaching of a pyrite. Previous studies suggested that the formation of jarosite in bioleaching systems reduces the dissolution kinetics of metallic sulfide [40,41]. However, it was found in this study that the precipitation of jarosite had little effect on the bioleaching process. As previously reported [42], jarosite presented as fluffy or woolly spherical particles, loosely packed in a porous structure on the surface, and a similar conclusion was reached by previous works $[43,44]$. It should be noted that, considering that the sterile control had no significant effect on the oxidation of DRGO, no analysis was conducted in the subsequent process.

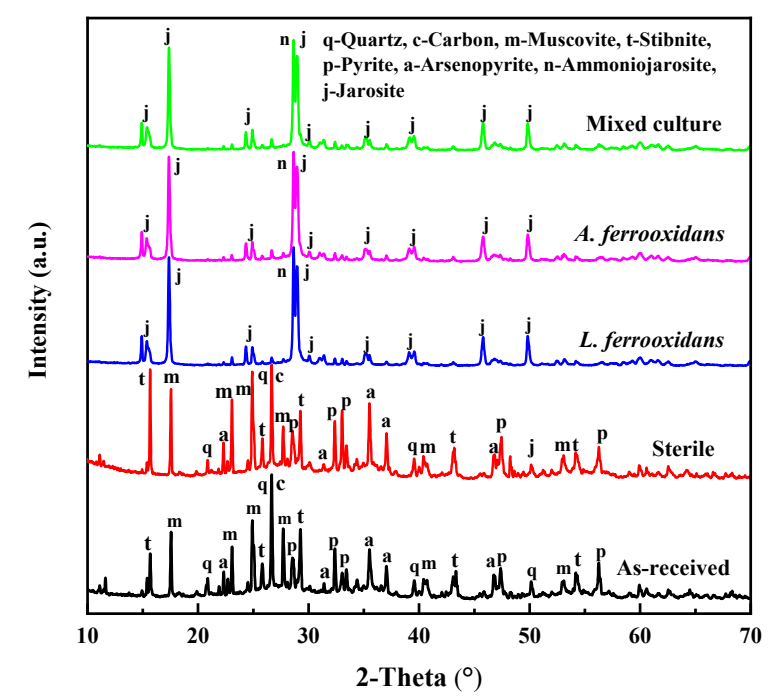

Figure 2. XRD diffraction patterns for the as-received, bio-oxidized and sterile control DRGO.

\subsubsection{Morphology Analysis by SEM-EDS}

High-magnification SEM images and EDS data of DRGO using different cultures are shown in Figure 3. In Figure 3a, the SEM image showed that the DRGO surface was smooth before treatment, and the atomic percentage of $C$, As and $S$ in the as-received DRGO was $16.87 \%, 0.91 \%$ and $22.07 \%$, respectively (spot a-1). After 1 day of bio-oxidation, there were many small crystalline flocs visible on the mineral surface, as seen in Figure $3 b, e, h$. According to the EDS analysis, the atomic percentages of elemental C, O and S on the mineral surface were significantly increased, indicating that DRGO was oxidized and CM was released. In addition, it was accompanied by the formation of a large amount of elemental sulfur and precipitates with high oxygen content (Equations (5), (8) and (9)). However, the element content varied greatly in different ore sites-this was because the bacterial attachment to the metal sulfide did not occur randomly. In other words, these bacteria, such as A. ferrooxidans, were preferentially attached to sites with visible defects on the surface [38]. Within 3 days of bio-oxidation, holes and cracks were clearly shown in Figure $3 c, f, i$. This suggested that the crystal lattice structure of the DRGO surface was partly disrupted following bio-oxidation. Meanwhile, the content of $\mathrm{O}$ on the DRGO surface was increased, but the $C$, As and $S$ contents were decreased, suggesting that the DRGO was further oxidized and elemental sulfur was oxidized by bacteria (Equation (4)). After 6 days of bio-oxidation, the mineral surface became granular and larger cracks or pits also appeared on the surface, and the SEM images (Figure $3 \mathrm{~d}, \mathrm{~g}, \mathrm{j}$ ) show that it was covered with many solid particles. According to the XRD analysis (Figure 2), it could be deduced that jarosite and ammoniojarosite were formed. In particular, the corrosion on mineral surfaces seemed more severe in the mixed culture (Figure 3j) than pure cultures. 

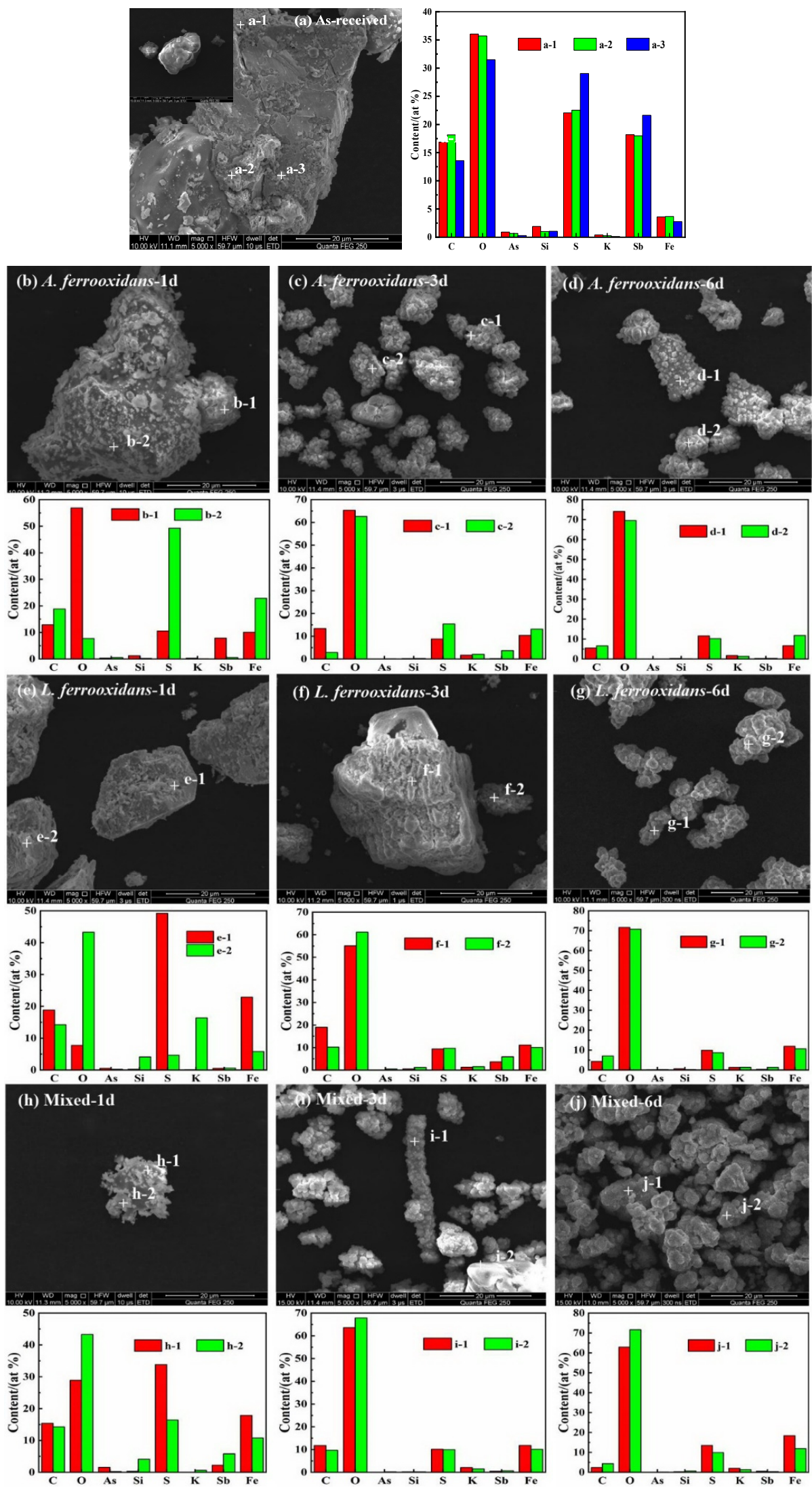

Figure 3. SEM images with EDS data (at.\%) for the as-received sample (DRGO) and the DRGO after oxidizing $1 \mathrm{~d}, 3 \mathrm{~d}$ and $6 \mathrm{~d}$ in $9 \mathrm{~K}$ culture medium. (a) As-received; (b-d) A. ferrooxidans; (e-g) L. ferrooxidans; (h-j) Mixed culture. 


\subsubsection{Chemical Bonds and Functional Groups Analysis by FTIR}

FTIR analysis was further carried out to verify the conversion of DRGO in the bio-oxidation process. By using differential spectra, where the "zero-moment" spectra (the spectra collected before the treatment) were subtracted from a series of spectrograms collected at different times, the difference spectra obtained would contribute to the understanding of the evolution of chemical structural changes $[45,46]$. The negative peaks in difference spectra mean the loss of chemical structure, while the positive peaks are a sign of the formation of new chemical structures [46]. As expected, the FTIR spectral peaks' shape and trend of samples were basically the same as shown in Figure 4a-c, indicating that these treatments had a parallel influence on the structure and composition distribution of functional groups in bio-oxidized DRGO. The differences in the bio-oxidized samples were mainly concentrated in the peaks and the intensity of some functional groups. Compared to the FTIR spectra of as-received DRGO, the main peaks of bio-oxidized samples included a strong broad peak of $3419 \mathrm{~cm}^{-1}$, which was attributed to O-H stretching vibration of water or Fe oxyhydroxides [47]. The new peak at $1427 \mathrm{~cm}^{-1}$ could be assigned to the $v_{3}$ stretching vibration of the C-O bond [48], suggesting that a mass of oxygen-containing groups were introduced on the surface of DRGO after bio-oxidation. Peaks at $1238 \mathrm{~cm}^{-1}$ and $1079 \mathrm{~cm}^{-1}$ could be assigned to the stretching vibration of $\mathrm{SO}_{4}{ }^{2-}$ [49], which was due to the bio-oxidation of pyrite and arsenopyrite, producing $\mathrm{SO}_{4}{ }^{2-}$ ions. The peak at around $971 \mathrm{~cm}^{-1}$ corresponded to $\mathrm{O}-\mathrm{H}$ bending vibration, which was ascribed to the adsorption of water onto the mineral surface [50].
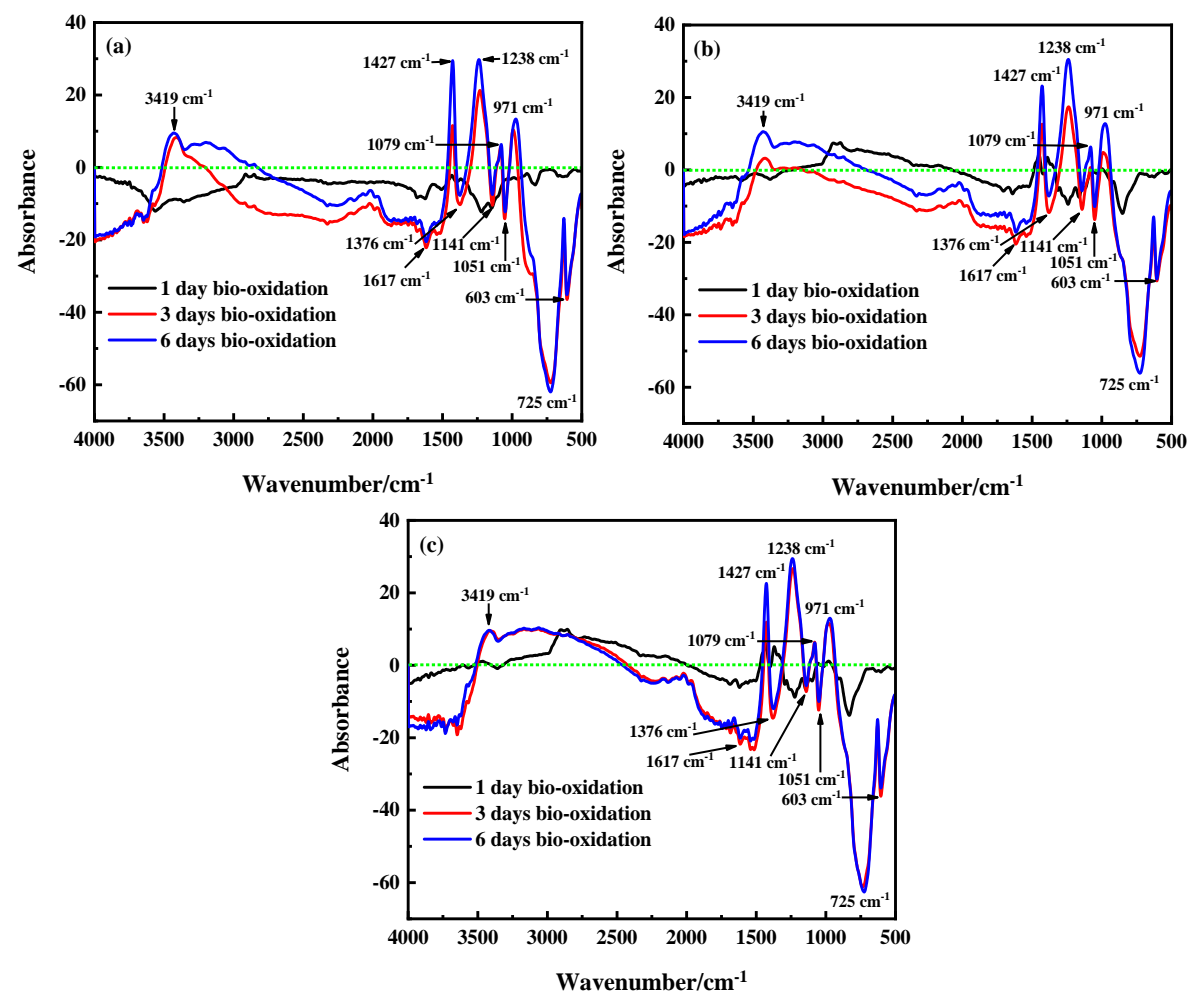

Figure 4. FTIR spectra (difference spectrum) of DRGO after oxidizing 1, 3 and 6 in $9 \mathrm{~K}$ culture medium. (a) A. ferrooxidans; (b) L. ferrooxidans; (c) Mixed culture.

In addition, negative peaks also occurred at $1617 \mathrm{~cm}^{-1}, 1376 \mathrm{~cm}^{-1}, 1141 \mathrm{~cm}^{-1}, 1051 \mathrm{~cm}^{-1}$ and $603 \mathrm{~cm}^{-1}$. The $\mathrm{C}=\mathrm{C}$ band around $1617 \mathrm{~cm}^{-1}$ was considered to be characteristic of the graphite hexagonal ring structure [51]. However, there was no significant interaction between highly ordered structures (such as graphite) and infrared radiation, and this absorption band might be due to the presence of polar functional groups or the irregularities of the aromatic structure, such as carboxylic acid groups or phenolic groups attached to aromatic rings [51]. Peaks at $1376 \mathrm{~cm}^{-1}$ and $1141 \mathrm{~cm}^{-1}$ 
were designated to the stretching vibration of the $\mathrm{O}-\mathrm{C}-\mathrm{O}$ and $\mathrm{C}-\mathrm{N}$ bands [52], respectively, suggesting that $A$. ferrooxidans and L. ferrooxidans could remove the aromatic compounds contained in the DRGO in the process of bio-oxidation. The peak at $1051 \mathrm{~cm}^{-1}$ referred to the bending vibration of the $\mathrm{O}-\mathrm{H}$ band [52], which was decreased, and this might be due to the fact that some substances of DRGO were coated with the sediment or converted from hydrophobic to hydrophilic nature brought about by bio-oxidation. In addition, the peak at $603 \mathrm{~cm}^{-1}$ was referenced as the stretching vibration of the S-S band [53], which indicated that sulfides were oxidized by $A$. ferrooxidans and L. ferrooxidans.

These results implied that DRGO could be effectively oxidized by A. ferrooxidans and L. ferrooxidans with time. However, the intensity of some functional groups tended to increase faster in mixed culture than in pure cultures, which was consistent with the results obtained from the changes in various indexes in solutions and the analyses of XRD, SEM and EDS in previous sections. In addition, bio-oxidation by A. ferrooxidans and $L$. ferrooxidans could significantly decrease the content of aromatic structures and introduce large quantities of oxygen-containing groups on the surface of DRGO. This phenomenon might result in reduced preg-robbing for gold in the subsequent thiourea leaching process.

\subsection{The Process of Sulfides Bio-Oxidation}

Gold occurred mainly in arsenopyrite and pyrite in the DRGO used in this study, and the diagrams of arsenopyrite and pyrite oxidation in Eh- $\mathrm{pH}$ coordinates are presented in Figure 5 . Since the bio-oxidation process was carried out under acidic conditions, the relevant range of $\mathrm{pH}$ values was $0-3$, where the phase changes were considered. As indicated, arsenopyrite was relatively unstable and it could be oxidized when $\mathrm{Eh}>-0.4 \mathrm{~V}$ under bio-oxidation conditions (Figure 5a-c). When the solution exhibited a low Eh $(-0.4 \mathrm{~V}-0.4 \mathrm{~V})$, iron existed mostly as $\mathrm{Fe}^{2+}$, while arsenic and sulfur presented mainly as $\mathrm{As}_{2} \mathrm{~S}_{2}, \mathrm{As}_{2} \mathrm{~S}_{3}, \mathrm{H}_{3} \mathrm{AsO}_{3}$ and $\mathrm{S}^{0}$. In the solutions of high $\mathrm{Eh}(>0.2 \mathrm{~V}$ ( $\mathrm{pH} 3)-0.4$ $\mathrm{V}(\mathrm{pH}$ )), the elements of iron, arsenic and sulfur in sulfide lattices were oxidized into $\mathrm{FeO} \cdot \mathrm{OH}$, $\mathrm{HAsO}_{3}{ }^{-} / \mathrm{H}_{3} \mathrm{AsO}_{4} / \mathrm{H}_{2} \mathrm{AsO}_{4}{ }^{-}$and $\mathrm{HS}_{2} \mathrm{O}_{3}{ }^{-} / \mathrm{S}_{2} \mathrm{O}_{3}{ }^{2-} / \mathrm{HS}_{2} \mathrm{O}_{4}{ }^{-}$, respectively. Furthermore, jarosite was easily formed between $\mathrm{H}_{3} \mathrm{OFe}_{3}\left(\mathrm{SO}_{4}\right)_{2}(\mathrm{OH})_{6}$ and $\mathrm{K}^{+}$in $9 \mathrm{~K}$ medium [54], and the precipitate could coat the surface of arsenopyrite in the presence of jarosite, $\mathrm{FeO} \cdot \mathrm{OH}, \mathrm{As}_{2} \mathrm{~S}_{2}, \mathrm{As}_{2} \mathrm{~S}_{3}$ and $\mathrm{S}^{0}$, which would impede the subsequent oxidation and leaching process. However, $A_{2} S_{2}, A_{2} S_{3}$ and $S^{0}$ could be oxidized by increasing Eh $(>0.4 \mathrm{~V})$.
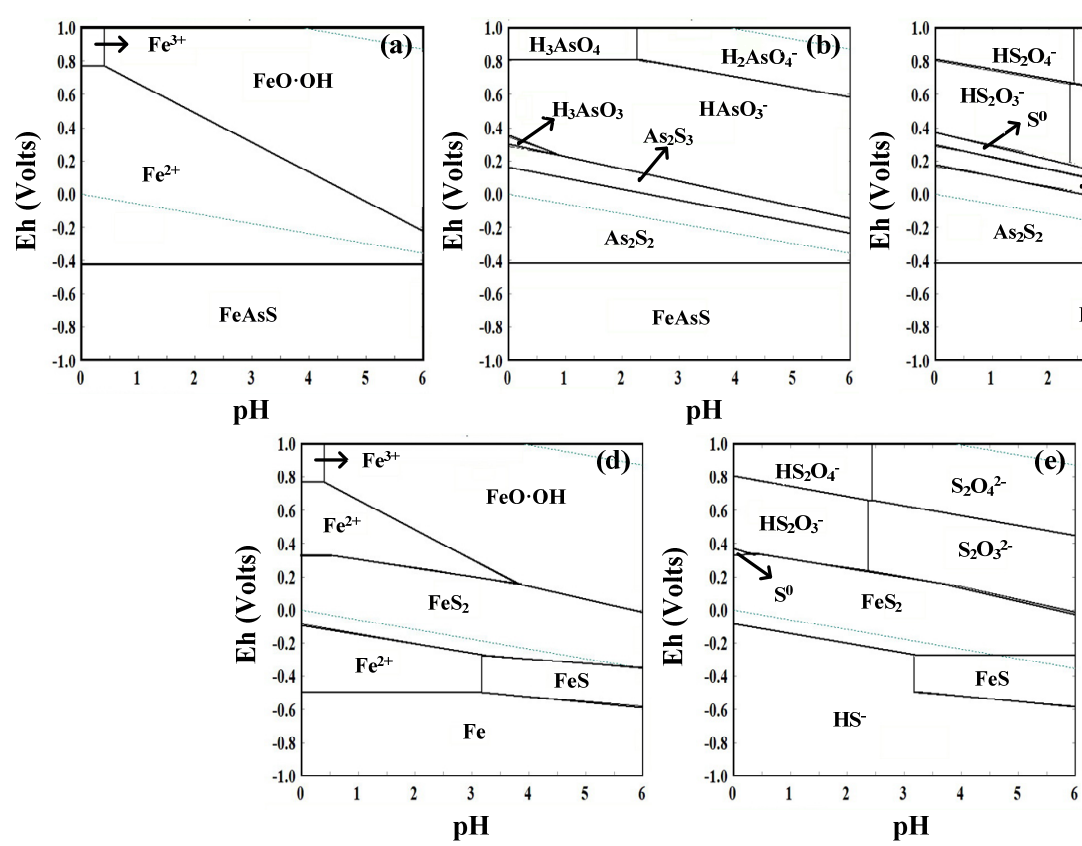

Figure 5. Eh-pH diagrams of Fe-As-S- $\mathrm{H}_{2} \mathrm{O}$ systems: (a) Fe species; (b) As species; (c) $\mathrm{S}$ species and Fe-S- $\mathrm{H}_{2} \mathrm{O}$ systems: (d) Fe species; (e) $\mathrm{S}$ species. Conditions: $\left[\mathrm{Fe}^{2+}\right]_{\text {total }} 0.16 \mathrm{M},[\mathrm{FeAsS}] 7.4 \times 10^{-4} \mathrm{mM}$, $\left[\mathrm{FeS}_{2}\right] 3 \times 10^{-4} \mathrm{mM} ; 25^{\circ} \mathrm{C}$ and $1 \mathrm{~atm}$. 
The data presented in the phase diagram for pyrite in the course of bio-oxidation (Figure 5d,e) show that the oxidation potential of pyrite was $-0.26 \mathrm{~V}$ to $0.33 \mathrm{~V}$ within the $\mathrm{pH}$ range of $0-3$. The oxidation potential of pyrite was significantly higher than arsenopyrite, indicating that the pyrite was more difficult to oxidize than arsenopyrite [55]. In the subsequent deeper oxidation process, the iron and sulfur species became $\mathrm{Fe}^{3+}, \mathrm{S}^{0}$ and $\mathrm{S}_{2} \mathrm{O}_{\mathrm{x}}{ }^{2-}$ at a higher $\mathrm{Eh}(>0.33 \mathrm{~V})$, while $\mathrm{Fe}^{2+}$, elemental iron and $\mathrm{HS}^{-}$ occurred at a lower Eh $(<-0.26 \mathrm{~V})$. It can be seen from the data that the $\mathrm{S}^{0}$ was gradually oxidized and the thiosulphate stabilizing effect could dominate with the increase in oxidation potential, which could accelerate the overall gold dissolution [56].

The above thermodynamic analysis demonstrated that the gold encapsulated in both arsenopyrite and pyrite could be liberated by bio-oxidation. In addition, the possible equilibrium equations involved in the bio-oxidation of arsenopyrite and pyrite are listed in Appendix A.

\subsection{Preg-Robbing Studies of DRGO in Thiourea System}

The effect of different bio-oxidation treatments on gold adsorption in the thiourea system is presented in Figure 6. It can be observed that the adsorption capacity of as-received DRGO to gold was $0.157 \mathrm{mg} / \mathrm{g}$ within $3 \mathrm{~h}$. After bio-oxidation, there was a decrease in the preg-robbing capacity of all samples, and the overall decrease in preg-robbing capacity was around $14 \%$. It was thus very clear that A. ferrooxidans and L. ferrooxidans possessed the ability to inactivate CM in DRGO and reduce its gold adsorption activity. It has been reported that the graphitic structure of CM was important for gold adsorption from the thiourea system [19]. However, there was an introduction of oxygen groups on the $\mathrm{CM}$, which had the potential to reduce the degree of graphitization and thus decrease gold adsorption activity. In addition, the cleavage of the aromatic $\mathrm{C}=\mathrm{C}$ band and the degradation of aromatic $\mathrm{O}-\mathrm{C}-\mathrm{O}$ and C-N bonds reduced the affinity of CM for gold in solution [57]. Another possibility was the reduction in the specific surface area via blocking the pores of CM by biochemicals produced from the microbial metabolism, hence reducing gold adsorption [58]. In addition, the coating of passivation materials such as jarosite reduced the effective contact between CM and gold. This conclusion was also reported in previous research from our team [59], where graphite was used as a substitute for CM. This observation might contribute to the increase in gold extraction from the bio-oxidized samples in the process of thiourea leaching.

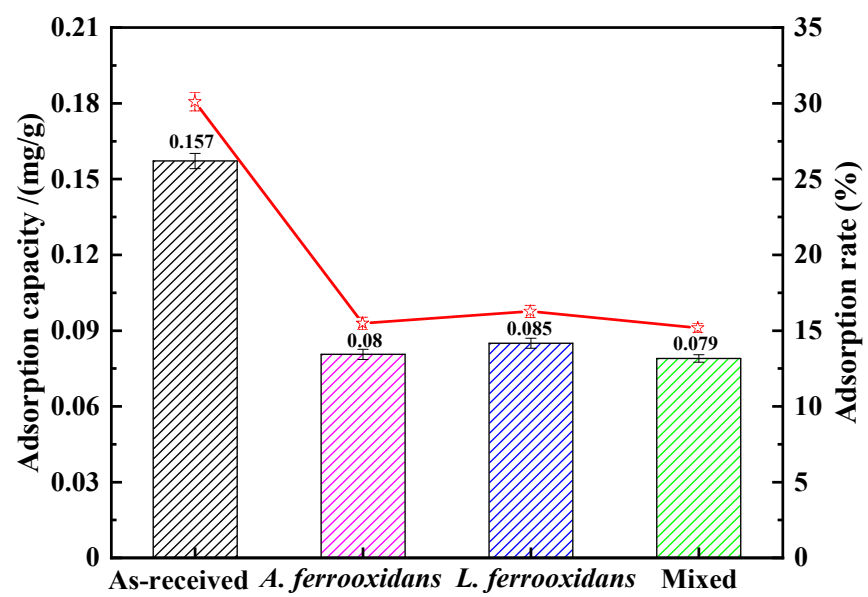

Figure 6. Effect of different treatments on gold adsorption by DRGO.

\subsection{Thiourea Leaching}

Leaching of gold was carried out in acidic thiourea solutions (Figure 7). It can be seen that the as-received DRGO yielded only around $28.7 \%$ of gold extraction by direct thiourea leaching, indicating that the present sample was very refractory. The recovery loss was mainly caused by the inaccessibility of thiourea reagent to gold particles and the preg-robbing of CM for gold in solutions. After biological 
pre-treatment, the gold recovery rate reached $78.69 \%$ (A. ferrooxidans) and $75.31 \%$ (L. ferrooxidans), and the DRGO oxidized by mixed culture resulted in higher gold extraction of $80.07 \%$. It can be seen that the mixed culture did not show any obvious advantage over the pure A. ferrooxidans and L. ferrooxidans in this study. This is inconsistent with previous reports [22,60]. However, this is possibly because the capacity of the strain varies depending on its source, pre-adaptation to minerals, the $\mathrm{pH}$ value of the solution and bacterial growth conditions [61]. In addition, compared with A. ferrooxidans, L. ferrooxidans has a stronger affinity for ferrous iron and is less sensitive to the inhibition of ferric iron [60]. Therefore, the use of mixed culture did not show obviously better bio-oxidation results than pure cultures, which may be related to the inferior iron oxidation ability of $A$. ferrooxidans at high potential. This finding is similar to the results reported earlier by Yang et al. [61] and Falco et al. [62]; both found that the synergistic effect of microorganisms with different metabolic pathways did not play an important role in their study.

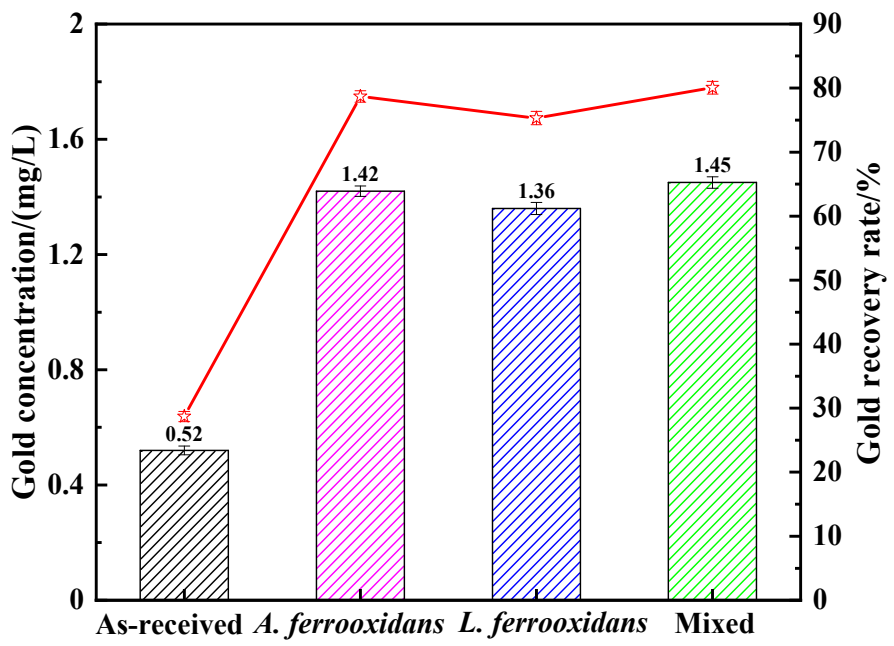

Figure 7. Effect of different treatments on gold recovery rates of DRGO.

\section{Conclusions}

This paper demonstrated that the bio-oxidation of a typical DRGO using A. ferrooxidans and L. ferrooxidans could decompose sulfides and simultaneously reduce the gold adsorption capability of $\mathrm{CM}$ in a thiourea system. Investigations showed that $A$. ferrooxidans and $L$. ferrooxidans were able to oxidize $\mathrm{Fe}^{2+}$ to $\mathrm{Fe}^{3+}$ and thus increase Eh in the solutions, which was conducive to decomposing the sulfides. This result was also proven by thermodynamic analysis. The preg-robbing capacity for gold was reduced by more than $14 \%$ after bio-oxidation. XRD, SEM-EDS and FTIR analyses showed that A. ferrooxidans and L. ferrooxidans were able to destroy the graphitization structure by the introduction of oxygen-containing groups, thus decreasing the active sites necessary for gold adsorption. Moreover, biochemicals were produced by microbial metabolism and passivation materials such as jarosite were formed on the surface of the DRGO, which prevented effective contact between CM and gold. In addition, the S-S band was cleaved, indicating that sulfides were oxidized by bacteria. Thiourea leaching results have shown that gold extractions of over $75 \%$ were achieved for both pure and mixed cultures. However, the use of mixed culture did not show obviously better bio-oxidation results than pure cultures. Preliminary results were promising, though there was still partial gold adsorption. Therefore, with optimized parameters in the process of bio-oxidation, higher levels of gold extraction and lower levels of preg-robbing are feasible.

Author Contributions: R.X. and Q.L.: Data curation, Writing, Original draft preparation, Conceptualization, Methodology, Funding acquisition. F.M.: Visualization, Investigation, Writing-Reviewing and Editing, Funding acquisition. Y.Y.: Software. B.X. and H.Y.: Writing-Reviewing and Editing. T.J.: Supervision, Validation. All authors have read and agreed to the published version of the manuscript. 
Funding: This research was funded by the National Key Research and Development Program of China (grant No. 2018YFE0110200), the National Natural Science Foundation of China (grant No. 51574284) and Science and Technology Planning Project of Yunnan Province (grant No. 2018ZE001)

Conflicts of Interest: The authors declare no conflict of interest.

\section{Appendix A}

Table A1. Possible equilibrium equations involved in the bio-oxidation of arsenopyrite and pyrite.

\begin{tabular}{|c|c|c|}
\hline Bio-Oxidation of Arsenopyrite and Pyrite & $\Delta \mathrm{G}^{0}{ }_{298} /(\mathrm{kcal} / \mathrm{mol})$ & No. \\
\hline $\mathrm{FeAsS}+5 \mathrm{Fe}^{3+}+3 \mathrm{H}_{2} \mathrm{O}=6 \mathrm{Fe}^{2+}+\mathrm{H}_{3} \mathrm{AsO}_{3}+\mathrm{S}^{0}+3 \mathrm{H}^{+}$ & -81.66 & 1 \\
\hline $2 \mathrm{FeAsS}+16 \mathrm{Fe}^{3+}+9 \mathrm{H}_{2} \mathrm{O}=18 \mathrm{Fe}^{2+}+2 \mathrm{HAsO}_{3}{ }^{-}+\mathrm{HS}_{2} \mathrm{O}_{3}{ }^{-}+15 \mathrm{H}^{+}$ & -211.199 & 2 \\
\hline $6 \mathrm{FeAsS}+12 \mathrm{Fe}^{3+}=3 \mathrm{As}_{2} \mathrm{~S}_{2}+18 \mathrm{Fe}^{2+}$ & -322.269 & 3 \\
\hline $\mathrm{FeAsS}+3 \mathrm{H}_{2} \mathrm{O}+6 \mathrm{Fe}^{3+}=7 \mathrm{Fe}^{2+}+\mathrm{S}^{0}+\mathrm{HAsO}_{3}{ }^{-}+5 \mathrm{H}^{+}$ & -91.489 & 4 \\
\hline $4 \mathrm{FeAsS}+4 \mathrm{H}_{2} \mathrm{O}+12 \mathrm{Fe}^{3+}=\mathrm{As}_{2} \mathrm{~S}_{3}+\mathrm{S}^{2-}+16 \mathrm{Fe}^{2+}+2 \mathrm{AsO}_{2}^{-}+8 \mathrm{H}^{+}$ & -194.989 & 5 \\
\hline $2 \mathrm{FeAsS}+6 \mathrm{H}_{2} \mathrm{O}+10 \mathrm{Fe}^{3+}=\mathrm{S}^{0}+2 \mathrm{HAsO}_{3}^{-}+\mathrm{S}^{2-}+12 \mathrm{Fe}^{2+}+10 \mathrm{H}^{+}$ & -126.894 & 6 \\
\hline $2 \mathrm{As}_{2} \mathrm{~S}_{2}+15 \mathrm{H}_{2} \mathrm{O}+16 \mathrm{Fe}^{3+}=4 \mathrm{HAsO}_{3}^{-}+2 \mathrm{~S}^{2-}+\mathrm{HS}_{2} \mathrm{O}_{3}^{-}+16 \mathrm{Fe}^{2+}+25 \mathrm{H}^{+}$ & -67.163 & 7 \\
\hline $\mathrm{As}_{2} \mathrm{~S}_{3}+9 \mathrm{H}_{2} \mathrm{O}+10 \mathrm{Fe}^{3+}=2 \mathrm{HAsO}_{3}^{-}+\mathrm{S}^{2-}+\mathrm{HS}_{2} \mathrm{O}_{3}^{-}+10 \mathrm{Fe}^{2+}+15 \mathrm{H}^{+}$ & -42.212 & 8 \\
\hline $\mathrm{FeS}_{2}+14 \mathrm{Fe}^{3+}+8 \mathrm{H}_{2} \mathrm{O}=15 \mathrm{Fe}^{2+}+16 \mathrm{H}^{+}+2 \mathrm{SO}_{4}^{2-}$ & -134.77 & 9 \\
\hline $\mathrm{FeS}_{2}+2 \mathrm{Fe}^{3+}=3 \mathrm{Fe}^{2+}+2 \mathrm{~S}^{0}$ & -19.164 & 10 \\
\hline $\mathrm{FeS}_{2}+3 \mathrm{H}_{2} \mathrm{O}+6 \mathrm{Fe}^{3+}=7 \mathrm{Fe}^{2+}+\mathrm{HS}_{2} \mathrm{O}_{3}^{-}+5 \mathrm{H}^{+}$ & -47.385 & 11 \\
\hline $\mathrm{S}^{0}+4 \mathrm{H}_{2} \mathrm{O}+6 \mathrm{Fe}^{3+}=\mathrm{SO}_{4}^{2-}+8 \mathrm{H}^{+}+6 \mathrm{Fe}^{2+}$ & -57.803 & 12 \\
\hline $\mathrm{Fe}^{3+}+3 \mathrm{H}_{2} \mathrm{O}=\mathrm{Fe}(\mathrm{OH})_{3}+3 \mathrm{H}^{+}$ & 5.503 & 13 \\
\hline $2 \mathrm{Fe}^{3+}+4 \mathrm{H}_{2} \mathrm{O}=2 \mathrm{FeO} \cdot \mathrm{OH}+6 \mathrm{H}^{+}$ & 1.07 & 14 \\
\hline
\end{tabular}

\section{References}

1. Agorhom, E.A.; Skinner, W.; Zanin, M. Upgrading of low-grade gold ore samples for improved particle characterisation using Micro-CT and SEM/EDX. Adv. Powder Technol. 2012, 23, 498-508. [CrossRef]

2. Kaksonen, A.H.; Perrot, F.; Morris, C.; Rea, S.; Benvie, B.; Austin, P.; Hackl, R. Evaluation of submerged bio-oxidation concept for refractory gold ores. Hydrometallurgy 2013, 141, 117-125. [CrossRef]

3. Wang, G.H.; Xie, S.B.; Liu, X.X.; Wu, Y.H.; Liu, Y.J.; Zeng, T.T. Bio-oxidation of a high-sulfur and high-arsenic refractory gold concentrate using a two-stage process. Miner. Eng. 2018, 120, 94-101. [CrossRef]

4. Yang, H.Y.; Liu, Q.; Song, X.L.; Dong, J.K. Research status of carbonaceous matter in carbonaceous gold ores and bio-oxidation pretreatment. Trans. Nonferrous Met. Soc. China 2013, 23, 3405-3411. [CrossRef]

5. Nanthakumar, B.; Pickles, C.A.; Kelebek, S. Microwave pretreatment of a double refractory gold ore. Miner. Eng. 2007, 20, 1109-1119. [CrossRef]

6. Luo, W.J.; Yang, H.Y.; Jin, Z.A. Study on the Gold Recovery of Double Refractory Gold Ore Concentrate by Biological Oxidation Pretreatment. Adv. Mat. Res. 2015, 1130, 379-382. [CrossRef]

7. Pyke, B.L.; Johnston, R.F.; Brooks, P. Characterisation and behaviour of carbonaceous material in a refractory gold bearing ore. Miner. Eng. 1999, 12, 851-862. [CrossRef]

8. Xu, B.; Yang, Y.B.; Li, Q.; Jiang, T.; Liu, S.Q.; Li, G.H. The development of an environmentally friendly leaching process of a high C, As and Sb bearing sulfide gold concentrate. Miner. Eng. 2016, 89, 138-147. [CrossRef]

9. Rawlings, D.E.; Dew, D.; du Plessis, C. Biomineralization of metal-containing ores and concentrates. Trends Biotechnol. 2003, 21, 38-44. [CrossRef]

10. Brierley, C.L. Biohydrometallurgical prospects. Hydrometallurgy 2010, 104, 324-328. [CrossRef]

11. Ma, S.J.; Luo, W.J.; Mo, W.; Su, X.J.; Liu, P.; Yang, J.L. Removal of arsenic and sulfur from a refractory gold concentrate by microwave heating. Miner. Eng. 2010, 23, 61-63. [CrossRef]

12. Rawlings, D.E.; Johnson, D.B. The microbiology of biomining: Development and optimization of mineral-oxidizing microbial consortia. Microbiology 2007, 153, 315-324. [CrossRef] [PubMed]

13. Gonzalez, R.; Gentina, J.C.; Acevedo, F. Biooxidation of a gold concentrate in a continuous stirred tank reactor: Mathematical model and optimal configuration. Biochem. Eng. J. 2004, 19, 33-42. [CrossRef]

14. Sand, W.; Gerke, T.; Hallmann, R.; Schippers, A. Sulfur chemistry, biofilm, and the (in)direct attack mechanism ? a critical evaluation of bacterial leaching. Appl. Microbiol. Biotechnol. 1995, 43, 961-966. [CrossRef] 
15. Glenn, J.K.; Morgan, M.A.; Mayfield, M.B.; Kuwahara, M.; Gold, M.H. An extracellular H2O2-requiring enzyme preparation involved in lignin biodegradation by the white rot basidiomycete Phanerochaete chrysosporium. Biochem. Biophys. Res. Commun. 1983, 114, 1077-1083. [CrossRef]

16. Tien, M.; Kirk, T.K. Lignin-Degrading Enzyme from the Hymenomycete Phanerochaete chrysosporium Burds. Science 1983, 221, 661-663. [CrossRef]

17. Tien, M.; Kirk, T.K. Lignin Peroxidase of Phanerochaete Chrysosporium. In Methods in Enzymology; Academic Press: San Diego, CA, USA, 1988; Volume 161, pp. 238-249.

18. Ofori-Sarpong, G.; Tien, M.; Osseo-Asare, K. Myco-hydrometallurgy: Coal model for potential reduction of preg-robbing capacity of carbonaceous gold ores using the fungus, Phanerochaete chrysosporium. Hydrometallurgy 2010, 102, 66-72. [CrossRef]

19. Ofori-Sarpong, G.; Osseo-Asare, K. Preg-robbing of gold from cyanide and non-cyanide complexes: Effect of fungi pretreatment of carbonaceous matter. Int. J. Miner. Process. 2013, 119, 27-33. [CrossRef]

20. Amankwah, R.K.; Yen, W.T.; Ramsay, J.A. A two-stage bacterial pretreatment process for double refractory gold ores. Miner. Eng. 2005, 18, 103-108. [CrossRef]

21. Zhang, J.; Zhang, X.; Ni, Y.; Yang, X.; Li, H. Bioleaching of arsenic from medicinal realgar by pure and mixed cultures. Process Biochem. 2007, 42, 1265-1271. [CrossRef]

22. Akcil, A.; Ciftci, H.; Deveci, H. Role and contribution of pure and mixed cultures of mesophiles in bioleaching of a pyritic chalcopyrite concentrate. Miner. Eng. 2007, 20, 310-318. [CrossRef]

23. Nguyen, V.K.; Lee, M.H.; Park, H.J.; Lee, J.U. Bioleaching of arsenic and heavy metals from mine tailings by pure and mixed cultures of Acidithiobacillus spp. J. Ind. Eng. Chem. 2015, 21, 451-458. [CrossRef]

24. Anderson, C.G. Alkaline sulfide gold leaching kinetics. Miner. Eng. 2016, 92, 248-256. [CrossRef]

25. Sun, C.B.; Zhang, X.L.; Kou, J.; Xing, Y. A review of gold extraction using noncyanide lixiviants: Fundamentals, advancements, and challenges toward alkaline sulfur-containing leaching agents. Int. J. Miner. Metall. Mater. 2020, 27, 417-431. [CrossRef]

26. Zhou, H.; Song, Y.S.; Li, W.J.; Song, K. Electrochemical behavior of gold and its associated minerals in alkaline thiourea solutions. Int. J. Miner. Metall. Mater. 2018, 25, 737-743. [CrossRef]

27. Syna, N.; Valix, M. Assessing the potential of activated bagasse as gold adsorbent for gold-thiourea. Miner. Eng. 2003, 16, 511-518. [CrossRef]

28. Chen, C.K.; Lung, T.N.; Wan, C.C. A study of the leaching of gold and silver by acidothioureation. Hydrometallurgy 1980, 5, 207-212. [CrossRef]

29. Hilson, G.; Monhemius, A.J. Alternatives to cyanide in the gold mining industry: What prospects for the future? J. Clean. Prod. 2006, 14, 1158-1167. [CrossRef]

30. Yannopoulos, J.C. The Extractive Metallurgy of Gold; Springer: New York, NY, USA, 1991.

31. Li, J.S.; Miller, J.D. Reaction kinetics of gold dissolution in acid thiourea solution using ferric sulfate as oxidant. Hydrometallurgy 2007, 89, 279-288. [CrossRef]

32. Gallagher, N.P.; Hendrix, J.L.; Milosavljevic, E.B.; Nelson, J.H.; Solujic, L. Affinity of activated carbon towards some gold(I) complexes. Hydrometallurgy 1990, 25, 305-316. [CrossRef]

33. Nakbanpote, W.; Thiravetyan, P.; Kalambaheti, C. Preconcentration of gold by rice husk ash. Miner. Eng. 2000, 13, 391-400. [CrossRef]

34. Konadu, K.T.; Huddy, R.J.; Harrison, S.T.L.; Osseo-Asare, K.; Sasaki, K. Sequential pretreatment of double refractory gold ore (DRGO) with a thermophilic iron oxidizing archeaon and fungal crude enzymes. Miner. Eng. 2019, 138, 86-94. [CrossRef]

35. Guo, Y.J.; Guo, X.; Wu, H.Y.; Li, S.P.; Wang, G.H.; Liu, X.X.; Qiu, G.Z.; Wang, D.Z. A novel bio-oxidation and two-step thiourea leaching method applied to a refractory gold concentrate. Hydrometallurgy 2017, 171, 213-221. [CrossRef]

36. Kirby, C.S.; Thomas, H.M.; Southam, G.; Donald, R. Relative contributions of abiotic and biological factors in Fe(II) oxidation in mine drainage. Appl. Geochem. 1999, 14, 511-530. [CrossRef]

37. Schippers, A.; Sand, W. Bacterial Leaching of Metal Sulfides Proceeds by Two Indirect Mechanisms via Thiosulfate or via Polysulfides and Sulfur. Appl. Environ. Microbiol. 1999, 65, 319-321. [CrossRef]

38. Rohwerder, T.; Gehrke, T.; Kinzler, K.; Sand, W. Bioleaching review part A: Progress in bioleaching: Fundamentals and mechanisms of bacterial metal sulfide oxidation. Appl. Microbiol. Biotechnol. 2003, 63, 239-248. [CrossRef] [PubMed] 
39. Nazari, B.; Jorjani, E.; Hani, H.; Manafi, Z.; Riahi, A. Formation of jarosite and its effect on important ions for Acidithiobacillus ferrooxidans bacteria. Trans. Nonferrous Met. Soc. China 2014, 24, 1152-1160. [CrossRef]

40. Fantauzzi, M.; Licheri, C.; Atzei, D.; Loi, G.; Elsener, B.; Rossi, G.; Rossi, A. Arsenopyrite and pyrite bioleaching: Evidence from XPS, XRD and ICP techniques. Anal. Bioanal. Chem. 2011, 401, 2237-2248. [CrossRef]

41. Corkhill, C.L.; Wincott, P.L.; Lloyd, J.R.; Vaughan, D.J. The oxidative dissolution of arsenopyrite (FeAsS) and enargite (Cu3AsS4) by Leptospirillum ferrooxidans. Geochim. Cosmochim. Acta 2008, 72, 5616-5633. [CrossRef]

42. Wang, H.M.; Bigham, J.M.; Jones, F.S.; Tuovinen, O.H. Synthesis and properties of ammoniojarosites prepared with iron-oxidizing acidophilic microorganisms at 22-65 degrees C. Geochim. Cosmochim. Acta 2007, 71, 155-164. [CrossRef]

43. Marchevsky, N.; Barroso Quiroga, M.M.; Giaveno, A.; Donati, E. Microbial oxidation of refractory gold sulfide concentrate by a native consortium. Trans. Nonferrous Met. Soc. China 2017, 27, 1143-1149. [CrossRef]

44. Zhu, P.; Liu, X.D.; Chen, A.J.; Liu, H.W.; Yin, H.Q.; Qiu, G.Z.; Hao, X.D.; Liang, Y.L. Comparative study on chalcopyrite bioleaching with assistance of different carbon materials by mixed moderate thermophiles. Trans. Nonferrous Met. Soc. China 2019, 29, 1294-1303. [CrossRef]

45. Nguyen, T.; Martin, J.; Byrd, E.; Embree, N. Relating laboratory and outdoor exposure of coatings: II. J. Coat. Technol. 2002, 74, 65-80. [CrossRef]

46. Martin, J.W.; Nguyen, T.; Byrd, E.; Dickens, B.; Embree, N. Relating laboratory and outdoor exposures of acrylic melamine coatings: I. Cumulative damage model and laboratory exposure apparatus. Polym. Degrad. Stab. 2002, 75, 193-210. [CrossRef]

47. Mazzetti, L.; Thistlethwaite, P.J. Raman spectra and thermal transformations of ferrihydrite and schwertmannite. J. Raman Spectrosc. 2002, 33, 104-111. [CrossRef]

48. Gunasekaran, S.; Anbalagan, G.; Pandi, S. Raman and Infrared Spectra of Carbonates of Calcite Structure. J. Raman Spectrosc. 2006, 37, 892-899. [CrossRef]

49. Lazaroff, N.; Melanson, L.; Lewis, E.; NicholasSantoro; CurtPueschel. Scanning electron microscopy and infrared spectroscopy of iron sediments formed by Thiobacillus ferrooxidans. Geomicrobiol. J. 1985, 4, 231-268. [CrossRef]

50. Fredd, C.N.; Fogler, H.S. The Kinetics of Calcite Dissolution in Acetic Acid Solutions. Chem. Eng. Sci. 1998, 53, 3863-3874. [CrossRef]

51. Painter, P.C.; Starsinic, M.; Squires, E.; Davis, A.A. Concerning the $1600 \mathrm{~cm}^{-1}$ region in the i.r. spectrum of coal. Fuel 1983, 62, 742-744. [CrossRef]

52. Sakthivel, R.; Das, B.; Satpati, B.; Mishra, B.K. Gold supported iron oxide-hydroxide derived from iron ore tailings for CO oxidation. Appl. Surf. Sci. 2009, 255, 6577-6581. [CrossRef]

53. Ofori-Sarpong, G.; Amankwah, R.K.; Osseo-Asare, K. Reduction of preg-robbing by biomodified carbonaceous matter-A proposed mechanism. Miner. Eng. 2013, 42, 29-35. [CrossRef]

54. Liu, J.Y.; Tao, X.X.; Cai, P. Study of Formation of Jarosite Mediated by Thiobacillus Ferrooxidans in 9K Medium. In Proceedings of the International Conference on Mining Science \& Technology, Amsterdam, The Netherlands, 12 October 2009; Ge, S., Liu, J., Guo, C., Eds.; Elsevier Science Bv: Amsterdam, The Netherlands, 2009; Volume 1, pp. 706-712.

55. Koslides, T. Pressure oxidation of arsenopyrite and pyrite in alkaline solutions. Hydrometallurgy 1992, 30, 87-106. [CrossRef]

56. Feng, D.; van Deventer, J.S.J. The effect of sulphur species on thiosulphate leaching of gold. Miner. Eng. 2007, 20, 273-281. [CrossRef]

57. Twum Konadu, K.; Sasaki, K.; Ofori-Sarpong, G.; Osseo-Asare, K.; Kaneta, T. Bio-Modification of Carbonaceous Matters in Gold Ore: Model Experiments Using Powdered Activated Charcoal and Cell-Free Extracts of Phanerochaete chrysosporium. Hydrometallurgy 2017, 168, 76-83. [CrossRef]

58. Moreira, M.T.; Feijoo, G.; Lema, J.M. Fungal Bioreactors: Applications to White-Rot Fungi. Rev. Environ. Sci. Biotechnol. 2003, 2, 247-259. [CrossRef]

59. Li, Q.; Shen, H.; Xu, R.; Zhang, Y.; Yang, Y.B.; Xu, B.; Jiang, T.; Yin, H.Q. Effect of Acidithiobacillus ferrooxidans and Leptospirillum ferrooxidans on preg-robbing of gold by graphite from thiourea leaching solution. J. Clean. Prod. 2020, 261, 9. [CrossRef]

60. Rawlings, D.E.; Tributsch, H.; Hansford, G.S. Reasons why 'Leptospirillum'-like species rather than Thiobacillus ferrooxidans are the dominant iron-oxidizing bacteria in many commercial processes for the biooxidation of pyrite and related ores. Microbiol. Read. 1999, 145, 5-13. [CrossRef] 
61. Yang, Y.; Harmer, S.; Chen, M. Synchrotron X-ray photoelectron spectroscopic study of the chalcopyrite leached by moderate thermophiles and mesophiles. Miner. Eng. 2014, 69, 185-195. [CrossRef]

62. Falco, L.; Pogliani, C.; Curutchet, G.; Donati, E. A comparison of bioleaching of covellite using pure cultures of Acidithiobacillus ferrooxidans and Acidithiobacillus thiooxidans or a mixed culture of Leptospirillum ferrooxidans and Acidithiobacillus thiooxidans. Hydrometallurgy 2003, 71, 31-36. [CrossRef]

(C) 2020 by the authors. Licensee MDPI, Basel, Switzerland. This article is an open access article distributed under the terms and conditions of the Creative Commons Attribution (CC BY) license (http://creativecommons.org/licenses/by/4.0/). 